\title{
IN VITRO FREQUENCY ANALYSIS OF SPLEEN COLONY-FORMING AND MARROW-REPOPULATING HEMOPOIETIC STEM CELLS IN THE MOUSE
}

\author{
Rob E. Ploemacher and Johannes P. van der Sluijs
}

\author{
Department of Cell Biology II and Immunology, Erasmus University, P. O. Box 1738, 3000 DR. \\ Rotterdam. The Netherlands
}

SUMMARY: An assay is described for Day-12 spleen colony-forming cells (CFU-S-12) and hemopoietic stem cells with marrow-repopulating ability (MRA) in the mouse using a miniaturized stroma-dependent bone marrow culture assay in vitro. Bone marrow cells are grown in liquid culture in microtiter wells, and the resulting adherent stromal layers are depleted of all hemopoietic activity by $20 \mathrm{~Gy}$ gamma irradiation. Subsequently, single cell suspensions containing stem cells are overlaid in a range of concentrations, and the presence of one or more emerging phase nonrefractive cell clones (cobblestone areas) in a single well scored as positive. The frequencies of cobblestone area-forming cells $(\mathrm{CAFC})$ are then calculated by employing Poisson statistics. It is shown that the CAFC Day-10 and CAFC Day-28 frequencies closely correlate with those of CFU-S-12 and MRA cells, respectively.

Key words: hemopoietic stem cells; long-term marrow culture; limiting dilution assay.

\section{INTRODUCTION}

The hematopoietic stem cell (HSC) compartment is hetereogeneous, and represents a hierarchy of primitive cells on the basis of decreasing ability to generate new stem cells, decreasing pluripotentiality and proliferative potential, and increasing turnover rate $(10,16)$. Marrow-repopulating ability (MRA) cells, which are more primitive than CFU-S Day 12, are able to repopulate the depleted bone marrow of potentially lethally irradiated mice with new CFU-C, CFU-S Day 12 , and cells that rescue secondary mice from radiationinflicted death $(7,10-12)$. The assessment of CFU-S selfrenewal (9), MRA, or long-term repopulating ability (LTRA) (8) necessitates the use of in vivo (re)transplantation studies. Moreover, frequency analysis of such HSC subsets requires the use of large numbers of mice to meet statistical requirements (6).

The development of routine techniques for in vitro assessment of CFU-S and MRA-LTRA frequencies should significantly reduce the use of animals in the laboratory, and provide a possible application in human hematological research, where no assays exist that allow frequency analysis of the most primitive HSC subsets.

The present study describes the essential methodology of a limiting dilution type miniaturized, long-term bone marrow culture (13) and summarizes an extensive correlative study of its application as an assay of CFU. S-12 and MRA numbers in a cell suspension. The method is based on the long-term bone marrow culture (LTBMC) in 25- $\mathrm{cm}^{2}$ flasks ( 1 ) and is done by overlaying cells on preestablished, irradiated stromal layers in microtiter wells instead of flasks (15). These layers are hemopoietically inactive but still support clonal growth of HSC and their descendants.

\section{MATERIALS}

A. Equipment Incubator, fully humidified, $\mathrm{B} 5060 \mathrm{EK} / \mathrm{CO}_{2}$, Heraeus ${ }^{2}$ Laminar-flow hood.

Gammacell 40 dual cesium-137 gamma source, $\mathrm{AEC}^{2}$

Mortar and pestle, sterile.

Inverted phase contrast microscope, CK-2, Olympus ${ }^{3}$

Multipette 4780, and sterile combitips $5 \mathrm{ml}$, 0030048.237, Eppendorf ${ }^{4}$

Cooled centrifuge, Minifuge GL4400

B. Chemicals

Beta-mercaptoethanol, 805740, Merck $^{\mathrm{s}}$

Biotin, B4501, Sigma ${ }^{6}$

Bovine albumin, Fraction V, A9647

Dulbecco's modified Eagle's medium (DMEM) powder, 10-331-23, Flow'

Dutton powder, 076-99999 P, GIBCOs

Fetal bovine serum (FBS), selected batch for optimal fibroblast and CFU.C culture, A 1115 L, Hyclone"

Ferro(III)-chloride, $3943^{5}$

HEPES, 043-05630 $\mathrm{H}^{\mathrm{s}}$

Horse serum, selected batch for optimal CFU-C growth, 034.06050 $\mathrm{M}^{\mathrm{s}}$

Human transferrin, OTRE 04/05, Behringwerke ${ }^{10}$

Hydrocortisone 21-hemisuccinate, sodium salt, $\mathrm{H}-4881^{6}$

Hydrogenchloride $37 \%, 13386^{5}$

L-Alanine, A-3534

L-Asparagine acid, A- $4534^{6}$ 
L-Cysteine, C-8152

L-Glutamic acid, 37102, BDH ${ }^{11}$

L-Glutamine, 1642, Baker ${ }^{12}$

L-Proline, P-4655 ${ }^{6}$

Penicillin G sodium salt, A 331-45, Seromed ${ }^{1.3}$

Sodium hydrogencarbonate $\left(\mathrm{NaHCO}_{3}\right), 6329^{5}$

Sodium hydroxide, $6498^{\circ}$

Sodium pyruvate, $6619^{s}$

Sodium selenite $\left(\mathrm{NSeO}_{1} \cdot 5 \mathrm{H}_{2} \mathrm{OI}, 6607^{5}\right.$

Streptomycin sulfate, A $331-27^{13}$

Vitamin B12, V-2876 $6^{6}$

C. Supplies

96 Wells microtiter plates, flat-bottomed ${ }^{8}$

Male CAB $\times$ C57Bl/F1 ice, 10-30-wk-old; bred and maintained at the Erasmus University Animals Centre under clean conventional conditions. Do not use $\mathrm{H}-2^{k}$ histocompatability type bme as second inoculum in LTBMC since they have a decreased long term maintenance $(2,14)$.

Sterile triple distilled water (TDW).

\section{PROCEDURE}

A. Preparation of solutions

1. Dutton's balanced salt solution (BSS)

a. Dissolve $11.79 \mathrm{~g}$ Dutton powder in 1 liter of triple distilled water (TDW).

b. Sterilize using a $0.22 \cdot \mu \mathrm{m}$ filter.

c. Store at $4^{\circ} \mathrm{C}$ in the dark.

In the following various supplements are described (A2-5) that allow preparation of an alpha-modified DMEM culture medium (A?). Finally, the LTBMC culture medium (A8) can then be prepared with solutions A6-7 and sera.

2. Dulbecco's modification of Eagle's medium

a. Dissolve the following in 1 liter of TDW

$13.66 \mathrm{~g}$ DMEM powder

$3.7 \mathrm{~g} \mathrm{NaHCO}_{3}$

$0.4 \mathrm{ml} \mathrm{37 \%} \mathrm{HCl}$

b. See A1, b and c

3. Supplement for alpha-modification of DMEM 1500 $\mathrm{ml})$

a. Put each of the following agents in a separate 25$\mathrm{ml}$ bottle and add $25 \mathrm{ml}$ of TDW

$1.25 \mathrm{~g}$ L-alanine; dissolve at $37^{\circ} \mathrm{C}$

$4.0 \mathrm{~g}$ L-asparagine acid; heat until dissolved

$3.5 \mathrm{~g}$ L-cysteine; add a few drops of $2 \mathrm{~N} \mathrm{HCl}$ to dissolve

$2.0 \mathrm{~g} \mathrm{~L}$-proline; dissolve at $37^{\circ} \mathrm{C}$.

5.5 g sodium pyruvate; dissolve at $37^{\circ} \mathrm{C}$.

b. Dissolve $2.5 \mathrm{~g} \mathrm{~L}$-asparagine and $3.75 \mathrm{~L}$-glutamic acid separately in $10 \mathrm{ml}$ of $2 \mathrm{~N} \mathrm{NaOH}$ and heat until dissolved.

c. Put all dissolved agents together with $5 \mathrm{ml}$ of a $0.25 \mathrm{mg}$ vitamin $\mathrm{Bl} 2$ per $\mathrm{ml}$ TDW stock solution and $5 \mathrm{ml}$ of a $0.30 \mathrm{mg}$ Biotin per $\mathrm{ml}$ BSS stock solution.

d. Adjust $\mathrm{pH}$ to 2.0 by adding $6 \mathrm{~N} \mathrm{HCl}$ and then adjust total volume to $500 \mathrm{ml}$ using TDW.

e. Sterilize by passing through a $0.22-\mu \mathrm{m}$ filter; can be kept for months when stored at $-20^{\circ} \mathrm{C}$.

4. Extra supplement for modification of DMEM (220 $\mathrm{ml)}$ a. Put the following solutions together:

$100 \mathrm{ml}$ of a $200 \mathrm{mM}$ L-glutamine stock solution $(2.92 \mathrm{~g}$ in $100 \mathrm{ml}$ TDW).

$100 \mathrm{ml}$ of a penicillin-streptomycin stock solution $\left(10^{4} \mathrm{U}\right.$ penicillin and $10 \mathrm{mg}$ streptomycin in 1 mI TDW).

$10 \mathrm{ml}$ of a $0.1 \mathrm{M}$ beta-mercaptoethanol stock solution $(50 \mu \mathrm{l}$ in $7.05 \mathrm{ml}$ TDW).

$10 \mathrm{ml}$ of a $10^{-4} \mathrm{M}$ sodium selenite stock solution $(2.63 \mathrm{mg}$ in $100 \mathrm{ml} \mathrm{TDW})$.

b. Sterilize by passing through a $0.22-\mu \mathrm{m}$ filter; can be kept for months when stored at $-20^{\circ} \mathrm{C}$.

5. Human transferrin (Fe-saturated)

a. Dissolve $1 \mathrm{~g}$ of purified human transferrin in 13 $\mathrm{ml}$ of TDW

b. Add $100 \mu \mathrm{l}$ of a $\mathrm{FeCL}_{3} \cdot 6 \mathrm{H}_{2} \mathrm{O}$ stock solution $10.7 \mathrm{~g}$ in $10 \mathrm{ml}$ TDW)

c. See Al b and c.

6. Hydrocortisone stock solution $\left(10^{-3} M\right)$

a. Dissolve $24 \mathrm{~g}$ of hydrocortisone 21-hemisuccinate sodium salt in $50 \mathrm{ml}$ of TDW.

b. Sterilize by passing through a $0.22 \cdot \mu \mathrm{m}$ filter; can be kept for months when stored at $-20^{\circ} \mathrm{C}$.

7. Alpha-modification of DMEM

a. Add $42 \mathrm{ml} \mathrm{TDW}$ and $20 \mathrm{mM}$ HEPES to $200 \mathrm{ml}$ of DMEM to obtain osmolality of $280 \mathrm{mOSM}$.

b. Add to $200 \mathrm{ml}$ of $280 \mathrm{mOSM}$ DMEM:

$2 \mathrm{ml}$ alpha supplement

$4.4 \mathrm{ml}$ extra supplement

$1.34 \mathrm{ml}$ human transferrin

c. Check osmolality ( 280 to $285 \mathrm{mOsM}$ ) and $\mathrm{pH}(7.2$ to 7.41 and store at $4^{\circ} \mathrm{C}$. Protect from light.

8. LTBMC medium

a. Add to $200 \mathrm{ml}$ of alpha-modified DMEM:

$25 \mathrm{ml}$ FBS

12.5 to $25 \mathrm{ml}$ horse serum (HS)

$2.5 \mathrm{ml}$ hydrocortisone stock solution

B. Preparation of bone marrow cells (BMC) for establishment of stromal layers

1. Kill mice by gassing with $\mathrm{CO}_{2}$. One mouse is required for setting up four microtiter plates $(240$ inner wells), which suffice for determination of the CAFC frequency of two cell suspensions. Take ou!t both sets of femur and tibia and place in ice-cold BSS. Remove muscles and tendons using paper towels, and rinse bones repeatedly to free them from tissue remainders.

2. Place bone in a sterile mortar (up to 100 femora and tibiae can be easily processed at a time) in a few milliliter of BSS with $5 \%$ FBS. Open bony shafts by grinding them with a pestle. Remove cell clumps from bones by repeated flushing using a wide-bore pipette $(5 \mathrm{ml})$. Collect the cell-rich medium from the mortar in a centrifuge tube and let it stand for 1 min. Collect the supernatant again and disregard the bony spicules at the bottom of the tube. Do not make single cell suspensions. Avoid violent stirring of the cell suspension at all times to preserve sufficient cell clumps required for optimal outgrowth of stromal elements. 
C. Preparation of bone marrow cells for stem cell assay

1. Follow steps 1 and 2 as described under B. A single BMC suspension is made by repeated flushing of the cells through a wide-bore pipette and subsequent sieving the cells once through a sterile 30 to $100-\mu \mathrm{m}$ gauze nylon sieve, framed in a pair of tightly fitting concentric steel rings that can be placed on top of a glass jar for collection of the sieved cells.

D. Setting up stroma

1. Dilute the bone marrow equivalent of one mouse (two hind legs) in $52 \mathrm{ml}$ of LTBMC medium. This volume is sufficient for filling the inner 60 wells of each of four microtiter plates with $0.2 \mathrm{ml}$ (about $5.10^{5} \mathrm{BMCl}$ each. The outer rim of wells may be filled with sterile water.

2. Put the cultures in a fully humidified incubator at $33^{\circ} \mathrm{C}$ and $10 \% \mathrm{CO}_{2}$. Start checking outgrowth of adherent clones at about Day 7 . If a confluent adherent layer develops within less than $10 \mathrm{~d}$, this is generally a sign of excessive macrophage outgrowth at the expense of fibroblastic and endothelial cells due to the HS batch. Inasmuch as this circumstance is associated with unstable and poorly supportive stromal layers, cultures should be terminated in this case and initiated again with a lower percentage of the HS batch used. Optimal layer development is associated with the appearance of phase contrast nonrefractile clones of round hemopoietic cells (cobblestone areas, CAs) under the stromal cells.

3. As soon as all well bottoms in a plate are covered by an adherent layer, plates are grouped in piles of four and wrapped in plastic bags for transportation and irradiation. Leaving the plates unirradiated after reaching confluency may lead to retraction of stromal layers at the well borders and subsequent -increasing loss of layer integrity. To completely eradicate endogeneous hemopoietic activity from the layers, plates are exposed to $20 \mathrm{~Gy}$ of gamma radiation. This treatment does not critically affect the ability of the LTBMC to support hemopoiesis $(3,5,17,18)$.

4. One day after irradiation, the medium in the wells is almost completely removed by suction through a sterile vacuum-operated needle, and fresh medium is deposited using a Multipette by flushing along the well wall to avoid dislocation of the stromal layer. The LTBMC medium should contain either $10 \%$ FBS and $10 \%$ HS, or $20 \%$ HS. Although the plates can be used as of this moment for overlay of fresh BMC, disappearing endogeneous $\mathrm{CAs}$ can be traced up to $3 \mathrm{~d}$ after irradiation. Irradiated layers can be maintained before reinoculation for $2 \mathrm{mo}$. and require a half medium change any 2 to 3 wk or when cultures turn acidic.

E. Setting up limiting dilution assay

1. Limiting dilution assay (LDA) of a particular cell suspension preferably requires the use of eight dilution steps, not more than two- to three-fold apart, and at least 15 wells per dilution (4). The number of cells in each aliquot is chosen so that a large fraction of cultures at a certain observation time do not contain any CAs. Normal murine BMC should be diluted as follows: 50000,25000 , $12500,6250,3125,1042,347$, and 116 cells per well $(0.2 \mathrm{ml}), 15$ wells per dilution. When $10 \mathrm{ml}$ of $2.5 \times 10^{5} \mathrm{BMC} \cdot \mathrm{ml}^{-1}$ is prepared, this suffices to inoculate 20 wells with the highest cell concentration and prepare all other dilutions.

2. Wells are half refed weekly.

F. Scoring of wells

1. As of Day 3, wells may be inspected for the presence of CAs that contain at least five cells, but may contain up to many thousands of nonrefractile cells. Inspection is done at $100 \times$ total magnification, using an inverted phase contrast microscope, by screening each well with vertical movements of the specimen holder in order to avoid nausea. Counting should not be done within $24 \mathrm{~h}$ after a medium change due to transient release of $\mathrm{CA}$ cells to the stromal surface and resulting underestimation of CA frequencies. A well is regarded positive if at least one CA is found.

G. Calculation of CA-forming cell frequencies

1. Evaluation of the LDA is performed by the maximum likelihood solution (4). From the fraction of nonresponding cultures, using the Poisson equation, it is then possible to calculate the frequency of CA-forming cells (CAFCs). It follows from this formula that if $37 \%$ of wells are negative an average of one CAFC per well has formed a clone. The percentage of negative wells in any dilution series is determined by the number of cells inoculated per well (13). In normal bone marrow of a variety of mouse strains we have observed CAFC Day- 7 frequencies between 1 in 200 to 1000 , and for CAFC Day-28 between 1 in 10000 to 50000 . The equilibrium between developing and disappearing CAs leads to a characteristic apparent CA half-life between Day 7 and 28 of about $3.6 \mathrm{~d}$, but half-lifes may be very different for fractionated cell suspensions. The method is extremely reproducible when using a single sex and mouse strain.

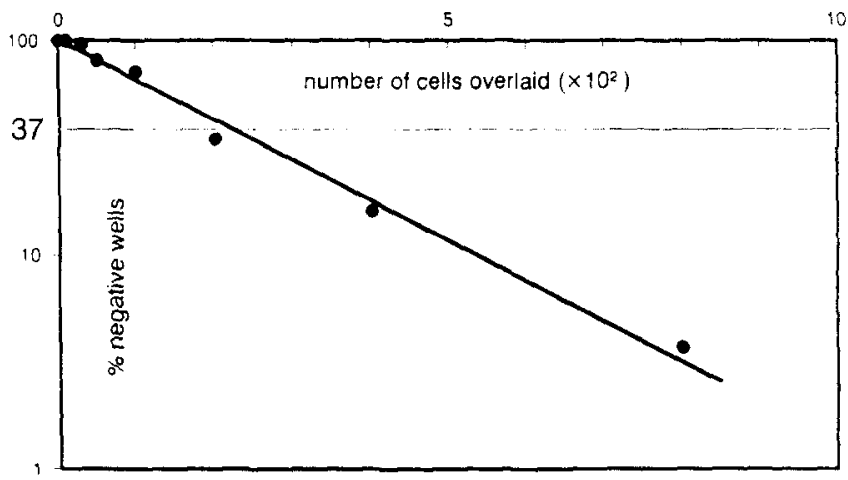

Flti. 1. Scoring of CAs as endpoint in limiting dilution analy sis of primitive precursor cells is strictly determined by the number of bone marrow cells overlaid on a preirradiated stromal layer. In this experiment, seven dilutions with 20 wells per aliquot counted on Day ? indicate a CAFC Day- 7 frequency of 1 in 240 bone marrow cells. 


\section{DISCUSSION}

The method as described should be considered as a technical note to our recent publication (13) on the use of LTBMC in frequency analysis of HSC subsets in vitro using a limiting dilution strategy. Our earlier demonstration of an association between the presence of $\mathrm{CAs}$ and replatable hemopoietic progenitor cells (CFU-C) in single wells tested indicates that scoring of $\mathrm{CAs}$ is a measure of the presence of early HSC in these cultures. However, the presence of refractile cells on top of the stroma does not indicate the presence of proliferating clones, because these cells are mostly mature and, in the case of macrophages, can be present for a long time after hemopoietic activity has ceased in a well. Our demonstration (13) that the presence of $\mathrm{CA}$ is strictly determined by the number of BMC overlaid on the stroma indicates single-hit kinetics of this system.

In an attempt to support our earlier statement (13) that a time-dependent cobblestone area formation exists that reflects the turnover time and primitiveness of CAFC, we have made extensive comparisons between in vivo (CFU-S Day 7 and Day 12, MRA cells) and in vitro (CAFC) assays for HSC. To this purpose we have prepared a variety of BMC fractions by means of physical sorting using density centrifugation, centrifugal elutriation, immunomagnetic bead adherence, sorting on the basis of forward and perpendicular lightscatter, wheatgerm agglutin fluorescein isothio-
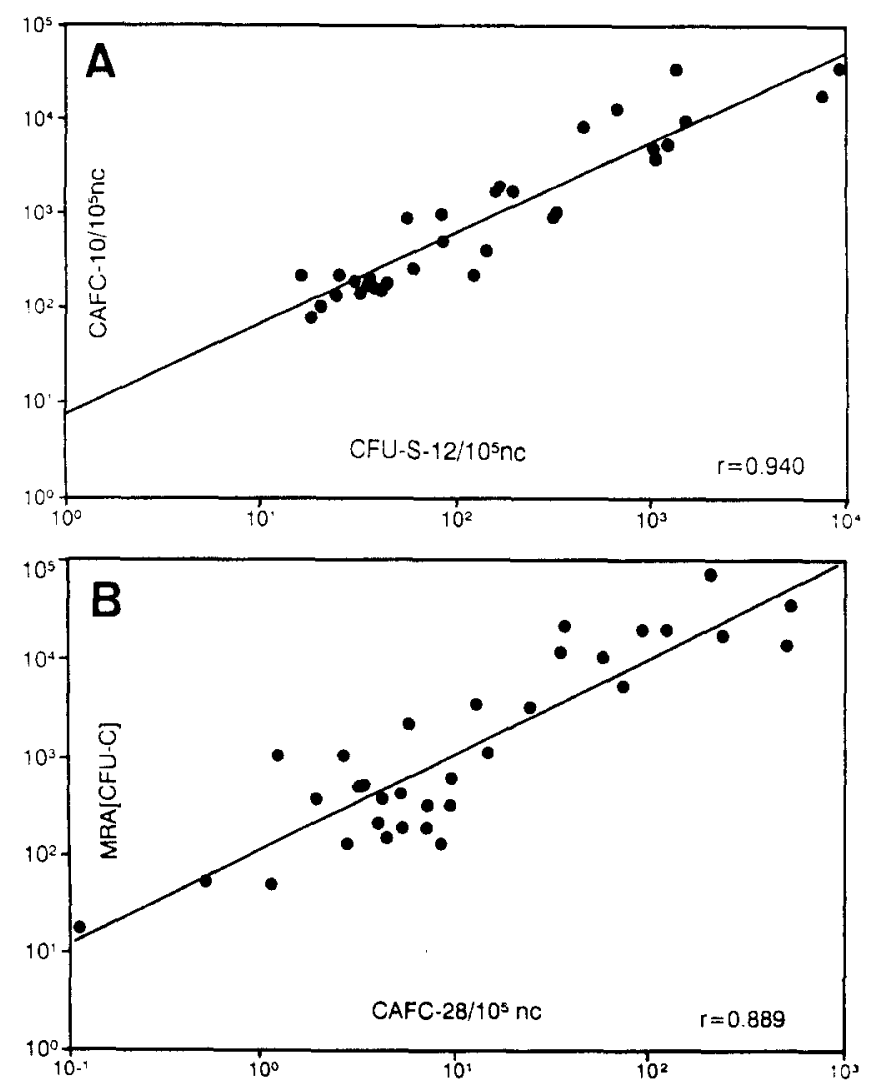

FIG. 2. Diagram showing high correlation between the incidence of CFU-S Day 12 and CAFC Day $10(A)$ and between the incidence of CAFC Day-28 and the ability of cells to generate new CFU.C in the irradiated femur over a 12 -d period (MRA[CFU-C]; $B$ ).

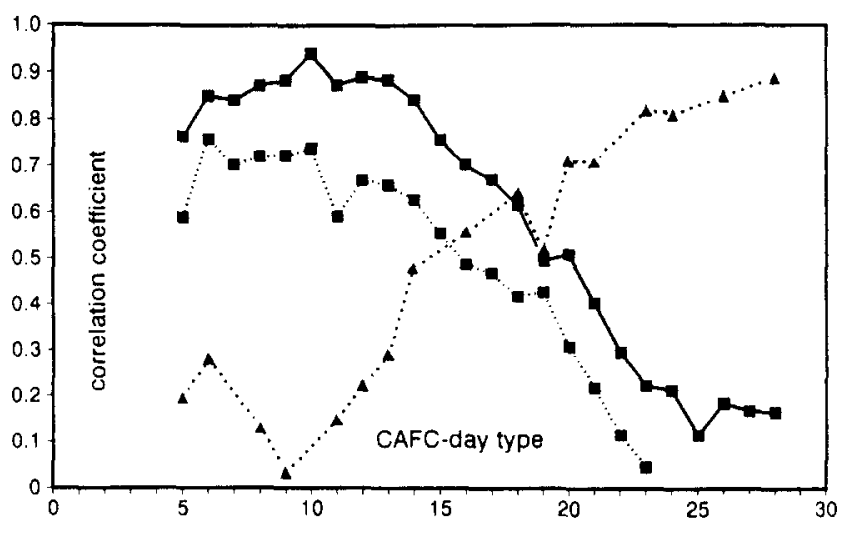

Fil. 3. Diagram showing the correlation coefficients between the CAFC frequencies as determined between Day 5 and 28 and the in-

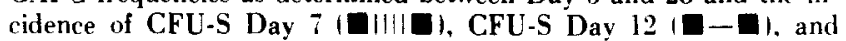
MRA[CFU.C] $1 \mathbf{A} \cdots)$ A

cyanate (FITC) affinity or retention of rhodamine-123. All these methods have been described in detail $(10,11)$, and essentially provide the researcher with cell suspensions in which the various HSC subsets occur in different frequencies. Figure 2 a shows a high correlation between CAFC Day 10 and CFU-S Day 12 $i r=0.940)$, whereas Fig. $2 b$ demonstrates correlation of CAFC Day 28 and primitive HSC with MRA $1 r=$ 0.889 ). Similar correlation diagrams were made for all CAFC day types and collected to give Fig. 3 . It is shown that the assay described gives excellent fitting with in vivo HSC assays permitting frequency analysis of the very primitive MRA cells.

\section{REFERENCES}

1. Dexter, T. M.; Allen, T. D.; Lajtha, L. G. Conditions controlling the proliferation of haemopoietic stem cells in vitro. J. Cell. Physiol. 91:335-344; 1977.

2. Dexter, T. M.; Spooncer, E.; Simmons, P., et al. Long-term marrow culture: an overview of techniques and experience. In: Wright, D. G.: Greenberger, J.S., eds. Long-term bone marrow culture. Kroc foundation series vol. 18. New York:Alan R. Liss; 1984:57-96.

3. Fabian. I.; Cline, M. In vitro analysis of the contributions of the adherent layer and recharging population to hemopoietic cell proliferation in long-term bone marrow cultures. Exp. Hematol. 19:319-325: 1981.

4. Fazekas de St. Groth. S. The evaluation of limiting dilution assays. J. Immunol. Methods 49:R11-R23; 1982.

5. Greenberger, J. S.; Cohen, G. I.; Sakakeeny, M. A. The development of a system for study of bone marrow transplantation in vitro: effects of $X$ irradiation dose rate and chemotherapeutic agents on the isolated bone marrow microenvironment. In: Wright, D. G.; Greenberger, J. S., eds. Long-term bone marrow culture. Kroc foundation series vol. 18. New York:Alan R. Liss; 1984:195-209.

6. Harrison, D. E.; Lerner, C. P.; Spooncer, E. Erythropoietic repopulating ability of stem cells from long-term marrow culture. Blood 69:1021-1025; 1987.

i. Hodgson, G. S.; Bradley, T. R.; Radley, J. M. The organization of hemopoietic tissues as inferred from the effects of 5-fluorouracil. Exp. Hematol. 10:26-35; 1982.

8. Magli, M. C.; Dick, J. E.; Huszar, D., et al. Modulation of gene expression in multiple hematopoietic cell lineages following retroviral vector gene transler. Proc. Natl. Acad. Sci. USA 84:789-793; 1987.

9. Mauch, P.; Greenberger, J. S.; Botnick, L. E., et al. Evidence for structured variation in self-renewal capacity within long-term bone marrow cultures. Proc. Natl. Acad. Sci. USA 77:2927-2930; 1980.

10. Ploemacher, R. E.; Brons, N. H. C. Cells with marrow and spleen repopulating ability and forming spleen colonies on day 16,12 and 8 are sequentially ordered on the basis of increasing rhodamine 123 retention. J. Cell. Physiol. 136:531-536: 1988. 
11. Ploemacher, R. E.; Brons, N. H. C. Isolation of hemopoietic stem cell subsets from murine bone marrow: I. Radioprotective ability of purified cell suspensions differing in the proportion of day- 7 and day-12 CFU.S. Exp. Hematol. 16:21-26; 1988.

12. Ploemacher, R. E.; Brons, N. H. C. Separation of CFU-S from primitive cells responsible for reconstitution of the bone marrow hemopoietic stem cell compartment following irradiation: evidence for a pre-CFU.S cell. Exp. Hematol. 17: 263-266; 1989.

13. Ploemacher, R. E.; van der Sluijs, J. P.; Voerman, J. S. A., et al. An in vitro limiting dilution assay of long-term repopulating hematopoietic stem cells in the mouse. Blood 74:2755-2763; 1989.

14. Reimann, J.; Burger, $H$. In vitro proliferation of haemopoietic cells in the presence of adherent cell layers. II. Differential effect of adherent cell layers derived from different organs. Exp. Hematol. 7:52-58; 1979.
15. Reincke, U.; Rosenblatt, M.; Hellman, S. An in vitro clonal assay of adherent cells (ASC) in mouse bone marrow. J. Cell. Physiol. 121:275-283;1984.

16. Rosendaal, M.; Hodgson, G. S.; Bradley, T. R. Organization of haemopoietic stem cells: the generation-age hypothesis. Cell Tissue Kinet. 12:17-29; 1979.

17. Spooncer, E.; Lord, B. I.; Dexter, T. M. Defective ability to self-renew in vitro of highly purilied primitive haematopoietic cells. Nature 316: 62-64; 1985

18. Zuckerman, K. S.; Prince, C. W.; Rhodes, R. K., et al. Resistance of the stromal cells in long-term bone marrow cultures to damage by ionizing radiation. Exp. Hematol. 14:1056-1062; 1986.

The authors are grateful to Mrs. Jane S. A. Voerman, Carin A. J. van Beurden, and Miranda R. M. Baert for technical assistance.

\footnotetext{
' Heraeus, Hanau, FRG

2 Atomic Energy of Canada, Ottawa, Canada

Olympus, Tokyo, Japan

' Eppendorf-Netheler-Hinz GmbH, Hamburg, FRG

' E. Merck, Darmstadt. FRG

"Sigma Chemical Co., St. Louis, MO, USA

'Flow Laboratories, McLean, VA, USA
}

\author{
* GIBCO Laboratories, Grand Island, NY, USA \\ "HyClone Laboratories Inc., Logan, Utah, USA \\ "Behringwerke AG, Marburg, FRG \\ ' BDH Chemicals Ltd., Poole, England \\ ' J.T. Baker Chemicals b.v., Deventer. The Netherlands \\ Seromed, Berlin, FRG \\ - Falcon, Becton Dickinson. Lincoln Park, NJ, USA
}

